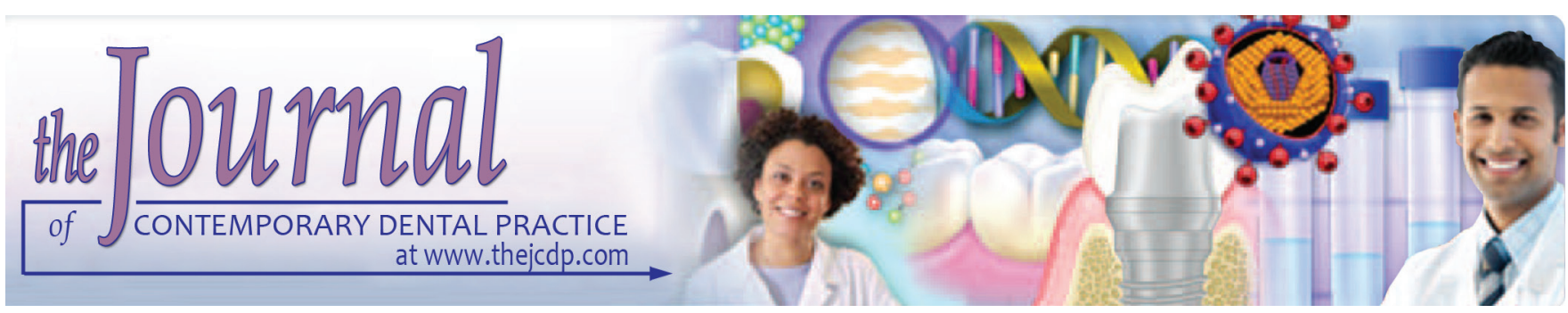

\title{
Clinical Assessment of Gingival Sulcus Width using Various Gingival Displacement Materials
}

\author{
${ }_{1}^{1}$ GB Goutham, ${ }^{2}$ Ipsita Jayanti, ${ }^{3}$ Md Jalaluddin, ${ }^{4}$ Anisha Avijeeta, ${ }^{5}$ Pavithra K Ramanna, ${ }^{6}$ Joseph Joy
}

\begin{abstract}
Aim: This study aims to compare the clinical efficacy of three different gingival retraction systems on gingival sulcus width.

Materials and methods: Study was conducted on prepared right or left maxillary central incisor for 45 subjects. Totally, 15 patients were randomly allocated in three gingival displacement groups, i.e., group I (retraction cord impregnated with aluminum chloride), group II (magic foam), and group III (laser). The pre- and postdisplacement impressions were made with addition silicone material using two-stage double mix technique.

Results: There was no difference between the groups at baseline. Group III produced more displacement (mean value 0.48 $\pm 0.101 \mathrm{~mm}$ ) than group II (mean value $0.31 \pm 0.09 \mathrm{~mm}$ ) and group I (mean value $0.44 \pm 0.11 \mathrm{~mm}$ ), and this was statistically significant.
\end{abstract}

Conclusion: Laser gingival displacement system was found to be effective among the three retraction systems. Choice of gingival displacement system is based on clinical situation and choice of operator.

Clinical significance: The retraction groups in the study created greater amount of gingival retraction than the least sulcus width required for the elastomeric impression material and so are clinically useful.

Keywords: Aluminum chloride, Gingival displacement, Laser, Magic foam.

\footnotetext{
${ }^{1}$ Department of Prosthodontics, College of Dental Sciences Davangere, Karnataka, India

${ }^{2-4}$ Department of Periodontics and Oral Implantology, Kalinga Institute of Dental Sciences, Kalinga Institute of Industrial Technology, Bhubaneswar, Odisha, India

${ }^{5}$ Department of Prosthodontics and Crown and Bridge, Vydehi Institute of Dental Sciences and Research Hospital, Bengaluru Karnataka, India

${ }^{6}$ Department of Conservative Dentistry and Endodontics, Mar Baselios Dental College, Kothamangalam, Kerala, India

Corresponding Author: GB Goutham, Department of Prosthodontics, College of Dental Sciences, Davangere Karnataka, India, e-mail: gouthamgb1@gmail.com
}

How to cite this article: Goutham GB, Jayanti I, Jalaluddin M, Avijeeta A, Ramanna PK, Joy J. Clinical Assessment of Gingival Sulcus Width using Various Gingival Displacement Materials. J Contemp Dent Pract 2018;19(5):502-506.

Source of support: Nil

Conflict of interest: None

\section{INTRODUCTION}

The patients who have lost one or several teeth need a prosthetic substitute that can provide adequate masticatory, phonetic, and esthetic function. In the present era of high esthetic demands with improved patients' awareness, fixed prosthodontics plays a crucial role. ${ }^{1}$ The clinical success and longevity of fixed prosthesis depend on the vigilant and precise completion of many procedures. One of the challenging procedures is making an accurate impression. An impression is an imprint or negative likeness of the hard tissues of teeth, and the soft tissues surrounding structures. ${ }^{2}$

For making a good impression, it is important to create a clean dry field free of fluid and debris, and the gingival tissue should be displaced to expose the finish line. Effective gingival retraction, i.e., soft tissue, is displaced to expose the tooth surface more cervically, is required to register the prepared abutments and finish lines accurately. Gingival retraction is defined as the deflection of marginal gingiva away from a tooth. ${ }^{3}$ If margins of our preparations are supragingivally located, capturing them is relatively less traumatic and simple, but it is not esthetic. However, much of the time, the margins are placed subgingivally to achieve desired esthetics, but it can damage periodontal tissues. However, periodontal health can be maintained in the presence of subgingival margins, but it requires careful execution of the clinical procedures and well-fitting, properly contoured crowns. ${ }^{4}$ 
The goal for the management of gingival tissues and gingival esthetics is to maintain the normal appearance of healthy gingiva. Achieving this goal requires optimal health before treatment and minimal trauma during treatment. The best way of optimizing health and minimizing trauma is to avoid contacting the gingiva with restorative materials. $^{5}$

Gingival displacement techniques are classified as mechanical, mechanochemical, surgical, or any combination. Ideal requirements of gingival retraction agent are that a gingival displacement agent should be effective, safe both locally and systemically, and the effects should be spontaneously reversible, wearing off in a short time, and leaving no permanent tissue displacement. ${ }^{6}$

It is essential to have optimum knowledge to rationalize the use of materials and techniques that are employed for gingival displacement. Numerous advancements have occurred in impression-making and gingival displacement for fixed prosthesis in recent times. Hence, this study was conducted to compare the clinical efficacy of three different gingival retraction systems on gingival sulcus width.

\section{MATERIALS AND METHODS}

The study was conducted in the Department of Prosthodontics, Sri Rajiv Gandhi College of Dental Sciences and Hospital, Bengaluru, India. The patients aged more than 18 years requiring fixed prosthesis in upper anterior region with minimum of one abutment were selected. Written informed consent was taken from all the participants. However, the patients with gingivitis, periodontal disease, and any systemic disease were excluded.

\section{Sampling}

Sample size was calculated using formula ${ }^{7}$

$$
\mathrm{n}=\frac{2\left(\mathrm{Z}_{\mathrm{a}}+\mathrm{Z}_{1-\beta}\right)^{2 \sigma 2}}{\Delta^{2}}
$$

n-Sample size

$$
\begin{gathered}
Z_{a}-1.96 \\
Z_{1-\beta}-0.84 \\
\Delta^{2} \text {-Effect size }{ }^{2}
\end{gathered}
$$

Calculated sample size was 43 . Hence, a sample of 45 was taken and patients were randomly divided into three groups:

1. Group I-15 patients' gingival retraction was done using retraction cord impregnated with aluminum chloride with a safe concentration level of up to $25 \%$.

2. Group II-15 patients' gingival retraction was done by magic foam retraction system.

3. Group III-15 patients' gingival retraction was done by laser retraction system.

\section{Gingival Displacement and Impression Making}

Teeth were prepared with shoulder finish lines at the gingival crest level. To measure the initial sulcus width, predisplacement (baseline) impression was made with addition silicone material using two-stage double mix technique.

\section{Gingival Displacement}

Teeth on which retraction is to be done are made free of any debris and saliva.

In case of group I (retraction cord impregnated with aluminum chloride system), the required dimension of the retraction cord was taken according to the gingival biotype of the subject. Retraction cord was impregnated with aluminum chloride looped around the labial surface of the tooth and gently pushed into the sulcus with the gingival cord packer instrument. Retraction cord was removed after keeping for 10 minutes in the gingival sulcus.

In case of group II (magic foam cord retraction system), the cartridge was attached to the automixing gun and then the mixing syringe with intraoral tip was placed into the gingival sulcus and material was applied. After injecting the displacement material, the corresponding Comprecap was positioned on the abutment to push the material deep into the gingival sulcus. It was removed from the patient's mouth after 5 minutes.

In case of group III (laser retraction system), the diode laser machine with the initiated fiber tip having a diameter of $400 \mu \mathrm{m}$ was used for gingival displacement at $0.8 \mathrm{~W}$ power with a frequency of $25 \mathrm{kHz}$ in continuous mode. The displacement/retraction area was cleansed and rinsed with a light spray of water and dried with air. Topical esthetic gel is applied to gingiva of prepared tooth for 1 minute, then the initiated fiber tip was placed into the sulcus just inside the crest of gingiva with very light pressure and moved around the tooth in small paintbrush stroke.

Postdisplacement impressions were made immediately after retraction and evaluated in a similar manner as predisplacement impressions. The impressions were poured with Type IV dental stone using vacuum mixer and vibrator. After the final set of Type IV stone, casts were retrieved and trimmed to obtain a flat base. The midlines of maxillary central incisors were marked on buccal and palatal surfaces of the casts using digital caliper at cervical and coronal levels. They were divided in an apicocoronal direction with the midline as a reference point. Sectioned halves were analyzed. Optical microscope attached to Axiovision (AC Soft Imaging System Software) was used to measure the width of gingival sulcus. The measurement was made from the crest of gingival margin to the 
midbuccal surface of the tooth. The width of the sulcus at the crest of gingival margin was noted for both the halves. The mean of these two was considered as one reading. Pre- and postdisplacement sulcus width was calculated for the entire samples. The amount of lateral displacement was calculated by subtracting the predisplacement values from the postdisplacement values of all the sectional halves.

Data obtained were entered into Microsoft Excel and analyzed using Statistical Package for the Social Sciences software 20. Mean and standard deviation (SD) were calculated and analysis of variance was used to analyze the statistical significance.

\section{RESULTS}

Age of the participants in the present study ranged from 19 to 45 years with average age being 28 years. There was no significant difference in gender distribution (Graph 1) and predisplacement gingival width among the groups (Graph 2 and Table 1).

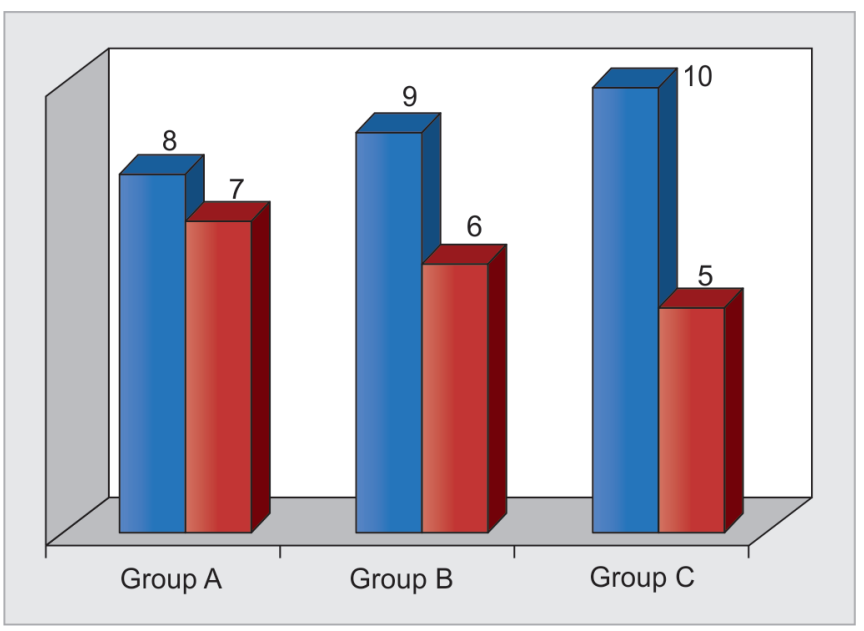

Graph 1: Gender distribution among study groups
The postdisplacement values of both the groups were analyzed, and it was found that group III produced more displacement (mean value $0.48 \pm 0.101 \mathrm{~mm}$ ) than group II (mean value $0.31 \pm 0.09 \mathrm{~mm}$ ) and group I (mean value 0.44 $\pm 0.11 \mathrm{~mm}$ ). This was found to be statistically significant (Table 2 and Graph 3).

Although numerically there was a slight difference in postdisplacement gingival sulcus width between group III (laser retraction system) and group I (retraction cord impregnated with aluminum chloride), it was not statistically significant (Table 3).

\section{DISCUSSION}

Nowadays, dentists want "smart" products designed to make their jobs easier, faster, and affordable. In current years, several gingival displacement systems have entered the dental marketplace, claiming to be fast, convenient, and effective. Keeping this in mind, this study attempted to determine the effectiveness of three commonly used gingival displacement systems.

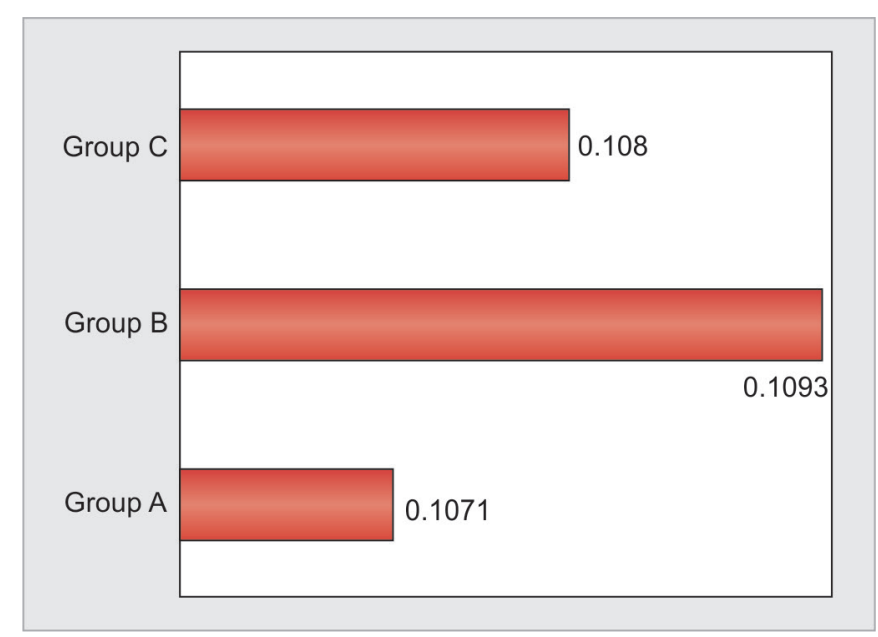

Graph 2: Mean width of gingival sulcus among study groups before gingival displacement

Table 1: Comparison of width of gingival sulcus among groups before gingival displacement

\begin{tabular}{|c|c|c|c|c|c|c|c|}
\hline \multirow[b]{2}{*}{ Groups } & \multirow[b]{2}{*}{$n$} & \multirow{2}{*}{$\begin{array}{l}\text { Mean gingival } \\
\text { displacement }(\mathrm{mm})\end{array}$} & \multirow[b]{2}{*}{$S D$} & \multirow[b]{2}{*}{ Standard error } & \multicolumn{2}{|c|}{ 95\% confidence interval for mean } & \multirow[b]{2}{*}{ Significance } \\
\hline & & & & & Lower bound & Upper bound & \\
\hline I & 15 & 0.1070 & 0.01612 & 0.00416 & 0.0991 & 0.1169 & 0.96 \\
\hline II & 15 & 0.1093 & 0.01668 & 0.00431 & 0.1001 & 0.1186 & \\
\hline III & 15 & 0.1080 & 0.01568 & 0.00405 & 0.0993 & 0.1167 & \\
\hline Total & 45 & 0.1084 & 0.01580 & 0.00236 & 0.1037 & 0.1132 & \\
\hline
\end{tabular}

Table 2: Comparison of gingival sulcus width among groups after gingival displacement

\begin{tabular}{|c|c|c|c|c|c|c|c|}
\hline \multirow[b]{2}{*}{ Groups } & \multirow[b]{2}{*}{$n$} & \multirow{2}{*}{$\begin{array}{l}\text { Mean gingival } \\
\text { displacement }(\mathrm{mm})\end{array}$} & \multirow[b]{2}{*}{$S D$} & \multirow[b]{2}{*}{ Standard error } & \multicolumn{2}{|c|}{$95 \%$ confidence interval for mean } & \multirow[b]{2}{*}{ Significance } \\
\hline & & & & & Lower bound & Upper bound & \\
\hline I & 15 & 0.4400 & 0.112 & 0.02895 & 0.3779 & 0.5021 & $0^{*}$ \\
\hline II & 15 & 0.3133 & 0.092 & 0.02364 & 0.2626 & 0.3640 & \\
\hline III & 15 & 0.4800 & 0.101 & 0.02619 & 0.4238 & 0.5362 & \\
\hline Total & 45 & 0.4111 & 0.1228 & 0.01832 & 0.3742 & 0.4480 & \\
\hline
\end{tabular}

*Statistically significant 
Clinical Assessment of Gingival Sulcus Width

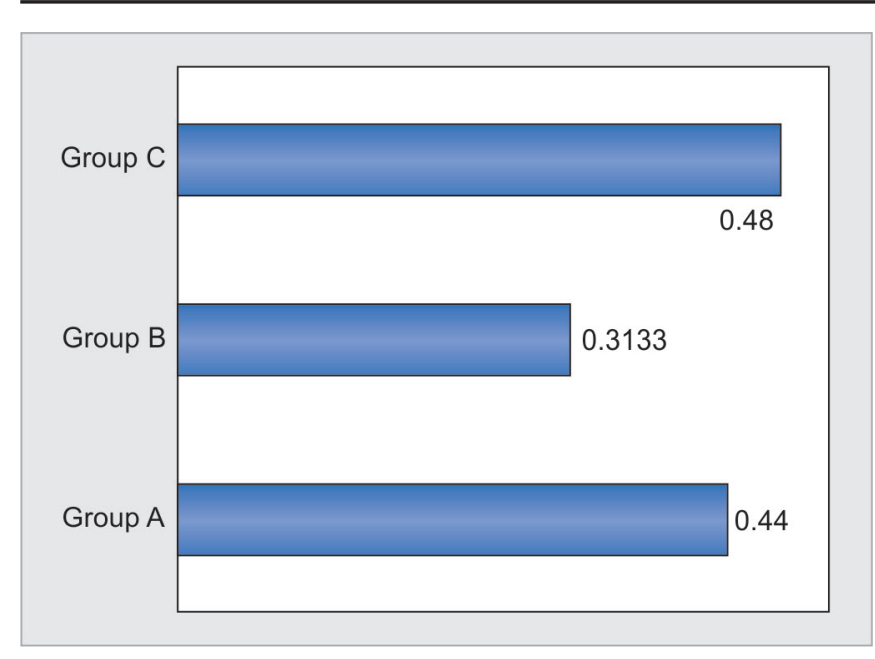

Graph 3: Mean gingival sulcus width among study groups after gingival displacement

Gingival displacement results in bending of gingival margin away from the tooth that will provide satisfactory horizontal-vertical space between the prepared tooth and gingiva to insert enough amounts of impression material. Forces, such as retraction, relapse, collapse, and displacement have a role in displacing the periodontal tissue. During gingival displacement in the natural teeth, periodontal fibers support the gingival fibers and to a degree reduce the tissue collapse after removal of retraction material.

After preparing the finish line of the abutment tooth, the marginal gingiva is retracted to avoid gingival fluid flow, the bleeding, and more penetration of the impression material. Following insertion of impression material into the gingival sulcus and removal of the tray after final material polymerization, a careful examination should be performed to assure that no impression material or retraction cords have been retained in the gingival sulcus because it may result in pain and periodontal inflammation. There are three general methods for gingival displacement including mechanical, chemical, and surgical methods. Gingival displacement techniques are classified as mechanical, mechanochemical, surgical, or any combination. Gingival displacing (retraction) agents should not cause certain permanent damage in adjacent tissues. However, sometimes, manipulation can result in tissue damage to some extent. However, this damage has to be reversible and recover within 2 weeks clinically and histologically. Maximum damage after the gingival displacement should not exceed $0.10 \mathrm{~mm}$. Even absorption of chemical gingival displacement agent into surrounding tissue should not result in any systemic side effect. ${ }^{8,9}$

In the present study, all the gingival retraction systems caused gingival displacement of more than $0.22 \mathrm{~mm}$, which is the optimal displacement required for recording of gingival finish lines. ${ }^{10}$ Hence, all the three gingival
Table 3: Comparison of gingival sulcus width among groups after gingival displacement

\begin{tabular}{lllll}
\hline & & & Standard & \\
Groups & $n$ & Mean $\pm S D$ & error mean & Significance \\
\hline I & 15 & $0.4400 \pm 0.11212$ & 0.02895 & 0.4 \\
III & 15 & $0.4800 \pm 0.10142$ & 0.02619 & \\
\hline
\end{tabular}

retraction systems are effective for gingival displacement. However, laser retraction system was the most effective among the three and least amount of displacement was caused by magic foam.

Chemical impregnated cords are a widely used technique of gingival tissue displacement. ${ }^{11}$ For gingival displacement, the cords are impregnated with chemicals. Among the chemicals, aluminum chloride is suitable because it causes minimal tissue damage in terms of inflammation, recession, and change in contour. ${ }^{12}$ Aluminum chloride solution (10\%) acts as hemostatic agent and astringent with its ability to precipitate protein and constrict blood vessels. ${ }^{13}$ Results of these studies were in accordance with the present study. Retraction cords impregnated with aluminum chloride are effective in gingival displacement than magic foam. The only drawback was that it was slightly time consuming and caused some discomfort in some patients. The same results were observed in studies conducted by Acar et al ${ }^{14}$ and Raghav et al. ${ }^{15}$

Magic foam, atraumatic gingival displacement method, expanding polyvinyl siloxane materials were designed for easy and fast retraction of the sulcus. ${ }^{15}$ It is less effective compared with the other two groups, but it was less time consuming than retraction cord. It was in accordance with the study conducted by Raghav et al. ${ }^{15}$

Soft tissue lasers can be used as an alternative to the usual retraction techniques because they provide adequate gingival displacement along with hemostasis with less working time and good patient comfort. ${ }^{16}$ In the present study, the laser retraction system was the most effective one, which is in accordance with studies conducted by Krishna et $\mathrm{al}^{16}$ and Dawani et al. ${ }^{17}$

These findings were in agreement with the study conducted by Gherlone et $\mathrm{al}{ }^{18}$ who pointed out that there was lower traumacity of the laser-assisted sulcus conditioning (980-nm diode and Nd:YAG) on the periodontium, as compared with conventional (surgical and mechanical) methods. The study concluded that the laser can be an important tool for obtaining anatomical information for fixed prosthesis and yielding correct results. In addition, during impression making, 980-nm diode laser may exhibit a higher hemostatic capacity than the Nd:YAG Laser.

In practice, laser gingival displacement system is generally used for preparing Chairside Economical Restoration of Esthetic Ceramics (computer-aided design/computeraided manufacturing) restorations. As in future dentistry, 
digital techniques might be used more commonly. Based on this premise, the supportive use of laser for gingival displacement is appropriate. ${ }^{19}$ However, from the affordability aspect, laser gingival displacement systems are costlier than other gingival displacement systems.

The limitations of the study are:

- The effects of gingival thickness, varied sulcus depth, visibility, and accessibility on the gingival displacement were not considered.

- Further studies are required to evaluate the effect of retraction on periodontal health after retraction as, in the present study, effectiveness is analyzed only based on gingival width of gingival sulcus.

- Only the maxillary central incisors are considered for the study, so further studies are required to evaluate several clinical sites in both maxillary and mandibular arches.

\section{CONCLUSION}

All the groups in the present study were clinically useful with acceptable impression qualities, as optimal gingival displacement was caused by all the three retraction systems. Laser gingival system was found to be effective among the three retraction systems, but there was no statistically significant difference between retraction cord and laser system. Choice of the appropriate gingival displacement system is also based on the particular clinical situation and preference of operator.

\section{REFERENCES}

1. Gupta D, Bhide SV, Gandhi PV, Paliwal J. Comparative evaluation of clinical efficacy of two different retraction systems-an in-vivo study. Indian J Stomatol 2012 Jan;3(1):7-13.

2. Rosenstiel, SF.; Land, MF.; Fujimoto, J. Contemporary fixed prosthodontics. 4th ed. China: Mosby; 2006. p. 431.

3. The glossary of prosthodontic terms. J Prosthet Dent 2005 Jul;94(1):10-92.

4. Koth DL. Full crown restorations and gingival inflammation in a controlled population. J Prosthet Dent 1982 Dec;48(6):681-685.
5. Wilson RD, Maynard G. Intracrevicular restorative dentistry. Int J Periodontics Restorative Dent 1981;1(4):34-49.

6. Jokstad A. Clinical trial of gingival retraction cords. J Prosthet Dent 1999 Mar;81(3):258-261.

7. Kadam P, Bhalerao S. Sample size calculation. Int J Ayurveda Res 2010 Jan-Mar;1(1):55-57.

8. Prasad KD, Hegde C, Agrawal G, Shetty M. Gingival displacement in prosthodontics: a critical review of existing methods. J Interdiscip Dent 2011 Sep;1(2):80-86.

9. Kumbuloglu O, User A, Toksavul S, Boyacioglu H. Clinical evaluation of different gingival retraction cords. Quintessence Int 2007 Feb;38(2):e92-e98.

10. Shivasakthy M, Asharaf Ali S. Comparative study on the efficacy of gingival retraction using polyvinyl acetate strips and conventional retraction cord-an in vivo study. J Clin Diagn Res 2013 Oct;7(10):2368-2371.

11. Kellam SA, Smith JR, Scheffel SJ. Epinephrine absorption from commercial gingival retraction cords in clinical patients. J Prosthet Dent 1992 Nov;68(5):761-765.

12. Shannon A. Expanded clinical uses of a novel tissue retraction material. Compend Contin Educ Dent 2002 Jan;23 (Suppl 1):3-6.

13. Land MF, Couri CC, Johnston WM. Smear layer instability caused by hemostatic agents. J Prosthet Dent 1996 Nov;76(5):477-482.

14. Acar Ö, Erkut S, Özçelik TB, Ozdemır E, Akçil M. A clinical comparison of cordless and conventional displacement systems regarding clinical performance and impression quality. J Prosthet Dent 2014 May;111(5):388-394.

15. Raghav D, Singh S, Kola MZ, Shah AH, Khalil HS, Kumar P. A comparative clinical and quantitative evaluation of the efficacy of conventional and recent gingival retraction systems: an in vitro study. Eur J Prosthodont 2014 Sep-Dec;2(3):76-81.

16. Krishna CV, Gupta N, Reddy KM, Sekhar NC, Aditya V, Reddy GV. Laser gingival retraction: a quantitative assessment. J Clin Diagn Res 2013 Aug;7(8):1787-1788.

17. Dawani M, Sathe S, Godbole SR. Comparative evaluation of clinical efficacy of two new gingival retraction systems-an in vivo research. Int J Sci Res 2016 Nov;5(11):4-10.

18. Gherlone EF, Maiorana C, Grassi RF, Ciancaglini R, Cattoni F. The use of 980-nm diode and 1064-nm Nd: YAG laser for gingival retraction in fixed prostheses. J Oral Laser Appl 2004 Fall;4(3):183-190.

19. Marsch A. Use of a diode laser for gingival troughing in conservative and prosthetic dentistry. Int Mag Laser Dent 2004;4:30-31. 